\title{
A Preliminary Study on School Experience and Its Practicality on Islamic Sexual Education for Transgender Children in Malaysia
}

\author{
Sa'dan Abdul Aziz ${ }^{1} \&$ Hazhari Ismail ${ }^{*}$ \\ ${ }^{1}$ School of Foundation Studies,Perdana University, Kuala Lumpur, Malaysia \\ ${ }^{2}$ Department of Early Childhood Education, Faculty of Human Development \\ Sultan Idris Education University, Tanjung Malim, Perak, Malaysia \\ *email: hazhari@fpm.upsi.edu.my
}

Received: 26 April 2020; Accepted: 02 December 2020; Published: 14 December 2020

To cite this article (APA): Abdul Aziz, S., \& Ismail, H. (2020). A Preliminary Study on School Experience and Its Practicality on Islamic Sexual Education for Transgender Children in Malaysia. EDUCATUM Journal of Social Sciences, 6(2), 50-60. https://doi.org/10.37134/ejoss.vol6.2.6.2020

To link to this article: https://doi.org/10.37134/ejoss.vol6.2.6.2020

\begin{abstract}
In a Malaysian school, transgender children and their sexual orientation pose a variety of challenges for them to fit in the school community. Nevertheless, school children who are transgender will still have to seek proper and fair schooling in their future. The purpose of this study is to identify and prepare transgender children for proper education on the basis of their gender identity and expression for those who is potentially becoming a transgender. The method adopted in the study was a qualitative approach by using a narrative literature review. As for the study, it was noticed that Malaysia is not yet in favour of promoting transgender children, notably in educational settings. During their school times, the majority of transgender people in Malaysia including children are found to suffer a greater challenge, persecution and bullied. Hence, there are four aspects to be highlighted: development of the policy, educational system, school counsellors and Islamic Sexual Education in order to prepare transgender children in school.
\end{abstract}

Keywords: Transgender, children, Islamic Sexual Education, Malaysia

\section{INTRODUCTION}

Child transgender problems are recent phenomena in Malaysia. As Ehrensaft (2009:13) states that children who have been identified as transgender are those who, " have already lived as the opposite gender for some time or upon entry into puberty; disclose sometimes with great urgency that they have never identified with the gender assigned to them at birth; and are horrified at the unwanted bodily changes showing their appearance". This could be inferred that certain transgender children understood that their given gender is in contrast to their sexual identity and speech (Olson \& Enright, 2017). With reference to the United Nation Convention on the Rights of the Infant (UNCRC), a child is someone below 18 years old unless the minimum age is met sooner under the national legislation of a nation itself.

Yik (1998) has found that there is an estimation of 10,000 transgender individuals in Malaysia, from 70-80\% Malays, accompanied by Chinese and Indian ethnic groups. Yik (2001), from a cultural and religious perspective on self-identity, has provided work on the transsexual phenomenon. The survey consisted of over 507 Mak-nyahs (transgender) from the 13 states of Malaysia. He discovered that $72 \%$ of respondents said that they are female-like and that $23 \%$ have sexual activity as a mixed boy and girl. In addition, $68 \%$ of respondents' have stated that they prefer girls' toys and $29 \%$ prefer to play boys' and girls' toys.

It has been found that 82 percent of respondents, in the research by Yik (2001), have chosen to be feminine during the activities. $17 \%$ of respondents both play woman and only $1 \%$ act as a child. The 
highest $68 \%$ of respondents play as a girl, $31 \%$ who mingle with boys and girl and only $1 \%$ of boys do. Payne (2013) illustrates a case of Coy Mathis, 6 years old, who had the right to use her girl's toilet in her school in Colorado, while she was assigned male sex when she was born. On the other hand, Ryland Whittington, an early childhood transgender girl with a women's identity at birth has been turned into a viral phenomenon on YouTube (Olson et. al, 2015). Hence, based on Ryland Whittington's story, after few months of intense debate, the Minnesota State High School League voted to allow transgender children to join other children's sport teams to express the gender identity instead of biological sex (Raddatz, 2014).

In Vietnam, about $85 \%$ of transgendered girls officially dropped out and faced assaults and bullying (Hoang and Nguyen, 2013). They were unable to graduate from high schools. Research, conducted in 2012/2013, in Thailand has found that quite an alarming number of schoolchildren who have described themselves as transgender or homosexually interested. The effects of them being bullied were related to higher absenteeism, mental health depression, unprotected and underage sex and attempted suicide (University of Mahidol, Plan International and UNESCO, 2014). School boards, administrators and teachers tries to improve oppressive school environments by endorsing policies that restrict or punish transgender students.

This means not acting passively against bullying transgender students by peers; asking awkward queries on the privacy of students; or using words or acts that are threatened, disruptive, or in risk. Such activity is tacitly accepted and continued by pupils, teachers and school administrators when the authorities did not take any actions (IGLYO, 2012). In Asia, the rules for haircut and school uniform style differ greatly from boy to girl. This rigid segregation of sex is particularly difficult for transgender children and young people and also for others who are gender nonconforming. Students dressing or behaving differently from such societal expectations on gender are regularly disciplined and refused the right to sit for exams.

\section{LITERATURE REVIEW}

\section{The landscape of transgender among children}

Open Society Foundations (2014) has outlined that the self-interest of the individual children are reflected in the sense of non-discrimination (Article 2), primary consideration (Article 3), the need to acknowledge the capacity of the child to make choices about his or her life (Article 5), and the opinions of the child must be responded to and given due concern in compliance with the child's age and maturity (Article 12). This could be commonly seen or known due to the presence of transgender children in most western countries. In 2012, for example, Argentina has already acknowledged the gender of law that allows those younger than 18 to change their registered sex to suit their gender identity (Article 5 of the Argentinean Gender Identity and Health Comprehensive Care for Transgender People Act). In this respect, the request is generally made by the child's legal guardian and for the sake of the request, the child must give its express consent. The legislation under the UNCRC takes into account the best interests of the child and the changing capacities. According to Brydum (2013), a transgender six-year old girl, who was assisted by the father, was officially recognised by the Buenos Aires Province administration in late September 2013. The second successful application was in October 2014 from a 10-year-old transgender child. In Europe, as a result of the Federal Constitutional Court ruling of 1982, Germany excluded the minimum age from its Transsexual Rule (German Federal Court, 1982). As a result, a transgender child under the age of 18 may sue for legal recognition of gender in court. Moreover, a transgender person, 12 years of age or older, has the right to be heard in such a case. In addition, Human Rights Watch Europe (2014) has stated that the equality for gender legislation of the Netherlands, which came into effect in July 2014, marginally decreases the age requirement by expanding eligibility to 16 and 17-year-old. Article 12 of the Gender Recognition Act passed in Ireland in July 2015 requires parents or guardians to qualify for a court exemption for a child aged 16 or 17 to the minimum age limit. Two medical professional certificates must be issued before a young person can be legally accepted in court. According to National School Climate Survey (2009), conducted by the Gay, Lesbian, and Straight Education Network in the United States, 84.6 percent of lesbian, gay, 
bisexual, and transgender students surveyed were sexually assaulted at school, 40.1 percent were pushed or hit, and 18.8 percent were kicked, punched or hurt by a gun (Kosciw et al., 2010).

According to clinical research conveyed by Olson (2016), parents have a choice to initiate a "gender change" by posing their children as opposite sex and even registering their children in kindergarten. In Luecke (2011) study, 65\% of students considered themselves confused at home because of their gender and almost $50 \%$ reported that a day or more of school was missed due to feeling uncomfortable (Greytak, Kosciw \& Diaz, 2009: 14). In addition, transgender laws of student rights have been implemented in two states, California and New Jersey (McCarthy, 2003). In addition, six colleges and universities have pro-actively implemented transgender non-discrimination inclusive rules and policies, and many others have been related to current transgender non-discrimination legislation (NonDiscrimination Legislation and School Policies).

The highest percentage of minimum age of children realising that they were transgender was reported at the age of eight (Mark, 2009). Nevertheless, transgender children between the age of 2 and 18 have less understanding of what it means to be a transgender. In Malaysia, there is no such law that has allowed transgender children to switch their gender after their maturity age. However, under the 2001 Child Act, children are labelled as children if they were below 18 years of age. This study focuses on transgender children up to the age of 17 after high school or Malaysian Certificate of Education (Sijil Pelajaran Malaysia) (SPM) examination.

A study was conducted by Zaini et al. (2004) on the character of mak nyahs (transwoman) at the Universiti Teknologi Malaysia (UTM) campus involving 125 students of female males, 500 male students and 460 UTM workers. It is reported that the Malays are of the highest population with 90.4 percent of the total number of respondents being feminine-male students. The second largest is the Indians with 5.6\% followed by the Chinese, 4\%. Zaini et al. (2004) has also investigated the mak nyahs' religion in UTM campus and found that $91.2 \%$ Islam, $4.8 \%$ Hindu, $4 \%$ Buddhist and $1.6 \%$ other religions.

\section{Malaysian Educational System and Transgender Children Experiences}

According to the Statistical Department Malaysia (2018), there are a total of 9.4 million children under 18 years of age out of the 32.4 million Malaysian total population. On the basis of this, 4,85,000,000 are males and 4,55,000,000 are females. There have been no studies on transgender children in Malaysia and there is no access to information on transgender children in Malaysia. There are many controversial and critical issues are we live among the transgender groups. Transgender children attend school with a lot of witchcrafts, mockery and threats as discussed by Kosciw et al. (2016).

Julia et al. (2018) have proposed that 80 percent of transgender children would prefer to accept themselves as "cisgender" as they matured. With 80 per cent expectations, transgender identity is a transitional "stage" in terms of transgender identity and language. In a study by Human Right Watch (2014), four transgender women were sexually abused and assaulted by students and their own teachers. Therefore, this research is based on transgender childhood and education experiences. At 14, Aisah one of the participants, started to use the hormone to grow her breasts. She mentioned her school male students were fond of squeezing her breast. She also stated that the teachers did not support her, but she was also squeezed by one of the teachers who were concerned about her (Human Right Watch, 2014). Sharan, an Indian transgender woman, at the age of 14, swas raped in a field outside school by a group of boys' students. She was in a stunned state at that time, and told herself that she was escaping because she could do nothing. A boy put her down on the floor and stripped her garments off and raped her anally. Seven of them were later also tried to rape her. By comparison, Natasha reminded a transgender in the state of Penang of her secondary education. She said the rest of the boys began taunting her, bullying her and making sexual advances, including holding her hands, squeezing her butt and rubbing her breast part. The boys would not leave the toilet when they went to the male bathroom and would label him "pondan" (Human Right Watch Report 2014).

As far as Non-Muslims are concerned, they have no right to be taught with Islamic sex education, but during the school time they have to learn on morals and civilization. Such topics can also be improvised and one or two transgender children topics can be added. Research by Vadevelu et al. (2018) have found that 7 of 18 respondents were rejected by family members because of their gender identity. They 
indicated that they were not. Three key kinds of negative actions have been registered, namely verbal violence.

"My mom was really upset with me because I was expelled out of school when one of the students in my school caught me having oral sex. My mom told my cousins and brother to beat me the moment I returned home. In my face and body, I suffered minor injuries (Vadevelu et al., 2018).

"Since she cannot agree that I am a transgender, I and my mum aren't in good terms. I have been angry and frustrating since childhood, since I always wanted to be a girl. My mother beats and slaps every time I behave like a girl's attitude. That's why I'll not stay with them when I'm 21 years old. Around the age of 13, because of this, I manage to leave home.

Lam Cheong, a 51 years-old transgender, recounted his struggles as a student relating to his school peers and was required to comply with social gender norms in a KRYSS study (2014). He told that:

Of course I was put in a girl's school. I couldn't even relate to my peers because I knew I was special when they started bad mouthed about teenage girl stuff ... I just didn't fit into it. I just couldn't. I've been born, but certainly didn't feel like wearing a skirt or shirt. That's why I didn't want to change in school ... I'd always think that I had to endure a life like a woman in women's attire to go to work (KRYSS 2014).

Besides that, Jess, a 20-year-old transwoman, remembered that boys in her school attempted to compel her to offer them oral sex after physical education class. The boys tried to beat her when she declined. Jess, which frightened them, stood her ground. The matter came to the counsellor of the school and the disciplinary unit, but Jess did not mention the offenders. For Aminah, a 30-year-old transwoman from Malay, she remembered her lives as an all-boys boarding school student, where sexual relations among boys were seen as a part of a beginning. Still, at school, Aminah's classmates humiliated her once they discovered her desire for a male fellow student.

Aminah told me: "A group of older people beat me up when I was thirteen for thinking that one of the senior was nice ... So I told him [my friend] that I like," I love it completely, "because I thought he was hot, somehow the words got around and he got the senior guy. But he wrote and confronted me with some of his seniors. They asked me I said something like that, and then beat me to say I like a boy (KRYSS, 2014).

Three studies on Muslim children of transgender in childhood were published in a research conducted by Ani Amelia and Zaleha (2016). The first instance, generally called the AA, was attributed to male sexual variation to male from female. AA was masculinized at the age of seven and had insisted that he was a "kid." The parents urged on her wearing woman's attire and behaving as a regular girl. Not only did AA fail to pray in a women's way, but she also declined to meet with a gynaecologist about her menstrual problem. AA met her parents and she asked them if she could pray as a man, marry a girl and be a good husband.

In another instance, BB suffers from female to male gender dysphoria. She also remembered that because of psychological issues she left high school. She felt miserable because when she was 13 years old, she found herself trapped in the male sex. Born into a Muslim family, she had to face conflicts when she asked her parents to reassign her gender. The parents asked her child to think deeper, however, as a religious Muslim person, it needed a legal procedure. Based on the previous interview with some NGOs and researchers, the majority of transgender children face persecution and challenges. It can be summarised that the secondary school was challenging for them to be transgender children. For instance, Aisah, Sharan, Natasha, Aminah had suffered sexual harassment by their schoolmates since during school times.

\section{Preschool}

Early childhood sex education focuses on the presentation, roles and function of body parts. The development of body anatomy for the body organs starts between the head and feet. In order to communicate differences to children, male and female organs are described. Particularly for the genital sections, a deeper explanation is needed and this is the part of the body which is considered a private area of someone that we cannot be shown to anyone. Wang Yuhong (2004) indicates that the one who should be teaching them are the pre-school teachers. Some still assume, however, that adults with a good sex education experience are qualified to teach pre-school children, which is not the case. 


\section{Primary school}

The Malaysian government has launched the module for health education at primary schools in 2014 (Ihwani et al, 2015). At this point, the children were taught sex education through other subjects, such as science teachers, where the human body and reproductive system are clarified thoroughly. Religious teachers, on the other hand, clarify the implications of transgender based on Islamic law, and moral teachers focus on social implications. The practicality of ISE should be addressed and assessed in greater depth and input should be given by the parent himself as a matter of sensitivity. A study done by Mohammad Kowsar (2014) describes the main source of sexual attitudes and beliefs by their parents regarding children. Nevertheless, Roziana et al. (2018) further clarify the growing incidence of sexual abuse against children such as rape, oral sex and molestation. It is almost certain that the incidence of sexual abuse is rising due to lack of information on Islamic sex education.

\section{Secondary school}

The Malaysian Sexual Education Course (MSE) which is intended for high school students was proposed (Azizah and Chan, 2008). As far as secondary school students are concerned, only the males and females learn about the reproductive system. It should also be pointed out that students should be exposed to transgender, who is in contrast to Malaysian cultures and religions and claim to be the third sex. The majority of them have already been educated as high school students and they can be taught on transgenderism in school. There are four aspects to be focused on, as recommended by Siti Suhaila et al. (2016), when planning the course such as personality, knowledge, skills and attitude. At this point they have to figure out how the male and the female children dress and vice versa to indicate their personalities. They do need to understand how transgender can become an opposing sex by undergoing a sex reassignment surgery which in Islam is explicitly forbidden. In terms of skills and behaviours, they should not be bullied by their peers, but they should be friends and seek to assist them in their gender assignment. This can be in many aspects such as the way to walk, speak, and dress.

\section{METHODOLOGY}

The study adopted a narrative literature review to explore the objective of the main issue. The purpose of this study is to identify and prepare transgender children for proper education on the basis of their gender identity and expression particularly for those who has the potential of becoming a transgender. This was done by exploring the education settings in each level. A narrative review was selected because it provides written discourses of the specific aims of the study from the point of theoretical perspectives. It uses a less formal approach where it does not require the demanding aspect when reporting the study (Jahan, et.al. 2016). However, it provides a detailed description on the issue.

\section{Data Collection}

4 steps were outlined in collecting the data, (1) Design, (2) Conduct, (3) Analysis and (4) Structuring and writing the review as detailed in Table 1 .

\begin{tabular}{|l|ll|}
\hline \multicolumn{1}{|c|}{ Steps } & \multicolumn{1}{c|}{ Explanation } \\
\hline Design & $\begin{array}{l}\text { Determine what are the contribution of conducting the review on the } \\
\text { children's transgender and who are the potential reader }\end{array}$ \\
- $\begin{array}{l}\text { Address the purpose and research questions of the study, as well as } \\
\text { the methodology }\end{array}$ \\
\hline Conduct & $\begin{array}{l}\text { Appraise the selection process of the related literature to children's } \\
\text { transgender, does it need adjustment or review? }\end{array}$ \\
\hline Analysis & $\begin{array}{l}\text { - Abstract the important information from the specific review. } \\
\text { - Check the quality and resources of the literature }\end{array}$ \\
\hline
\end{tabular}




\begin{tabular}{|l|ll|}
\hline & $\bullet$ & Plan how it could be reported and documented \\
\hline $\begin{array}{l}\text { Structuring } \\
\text { and } \\
\text { writing }\end{array}$ & $\begin{array}{l}\text { Prepare the standards and outlines, select the information that require } \\
\text { to be included in the report }\end{array}$ \\
\hline
\end{tabular}

Table 1: Steps in collecting data

\section{RESULT AND DISCUSSION}

The researchers only concentrate on children between the age of 3 and 17 as they are in elementary, primary and secondary school. The researchers discussed the problems faced by transgender children in their schooling and in the community in Islamic gender schooling. The children have their birth certificates or MyKid to confirm their specified genders at birth. Nevertheless, if the child is khunsa (hermaphrodite), it can be proven by a physician and then a single male or female sex must be selected. This can be clarified by examining the child's most functional genital component.

In order to prepare transgender children for a better life, they have the right for education. The consequences of bullying, abuse and discrimination against most transgender adults can be seen in the classroom. Most studies found that most transgender students did not complete their school due to gender identity crisis and language barrier. The approach was divided into three separate levels: elementary, primary school and high school children in order to address these obstacles.

\section{Pre-school transgender children}

The Minister of Education formed elementary or pre-school children in 1992 or commonly named prasekolah (Lily Muliana and Azman, 2013). Children aged 4 to 6 years of age are included in this group. There are two types of pre-schools which come from private and public providers in Malaysia. The public pre-school includes Prasekolah Kebangsaan, TABIKA, KEMAS, and State Department of Religious. Lily Muliana and Azman (2013) have found that 95.1\% of parents chose to send their children to pre-school based on Islamic background, but not all parents can send their children to Islamic preschool due to the fees. For pre-school children, gender is used to guide their choice in selecting the outfit (Halim et al., 2014) and toys (Eaton, Von Bargen \& Keats, 1981). This is because children may show their interests in other things on the basis of their sex. Anneliese \& Theodore (2009) further describe the roles of school counsellors in engaging with the child, teachers and parents. On the other hand, a research conducted by Mallon \& DeCrescenzo (2006) have stressed on the value of the supportive and positive school environment in which children can avoid depression and build selfesteem.

Therefore, the most beneficial strategy to care for transgender pre-school children is by coping with school counsellor's supervision of the children's parents. At this point, parents play a significant role in knowing the gender identity and behaviour of their children. According to Nazia (2016), parents should involve their kids by telling them about prayers, fasting, reciting Quran's Holy Book and other Islamic practices. When the child is still at the pre-school, the parents should lay a framework for the ongoing spiritual growth of Islamic learning.

\section{Transgender children for primary school}

In Malaysia, primary school children range from 7 to 12 years of age. This year, the increased levels of bullying was due to transgender children's visibility in primary schools. This is because pupils who are perceived as a sexual minority are exposed to discrimination irrespective of their actual sexual orientation (Varjas et al., 2008). Children in primary school might also be behaving violently towards transgender girls, such as physical assaults and verbal harassment. School counsellors should also advise and educate school workers on how to effectively respond to sexual identity or sexual harassment. Throughout the year, therefore, school counsellors could also give seminars for teachers 
and school administrators on how to efficiently engage with gender-oriented students from being bullied (Whitman et. al, 2007).

Policy enforcement in the school should be carried out for primary school transgender students. This policy framework is intended to ensure the fair treatment, anti-inflammation, and security of school policies for transgender children. Nevertheless, all measures must adhere to the general policy of safeguarding, fair treatment and anti-bullying of the school, and they must contribute to the security of the children's body by local authorities. Schools should be vigilant to provide transgender children with rights which other children do not get. Without making specific rules for a transgender girl, school rules should take a clear approach to preferences and personal style including clothing, hairstyles, and footwear.

\section{Transgender children for secondary school}

In Malaysia, the gap between elementary and secondary school children will be between the age of 13 and 17. In a primary school, transgender children are more aggressive than in elementary and secondary school. Research conducted by the Malaysian National Human Rights Society (2018) has shown that, between 2012 and 2015, in schools there were over 14,000 bullying incidents, most of which were physical bullying. The number of secondary school cases has slightly risen from $0.06 \%$ in 2015 compared to 0.11\% in 2014. Goodrich and Luke (2009), Singh and Burnes (2009), and Simons et al. (2018) have appealed for more transgender and gender non-conforming professional school counsellors in the classrooms, but some professional school counsellors did not abide to such request.

This may be because the scholars such as Shi and Doud (2017) and McCabe and Rubinson (2008) have shown the variability in the level of expertise in dealing with transgender students among educational practitioners, including school counsellors. Therefore, schools in Malaysia need to train school counsellors to plan for better education for transgender children. The main component is the one to one and vis a vis meeting which should be private and confidential in between school counsellors and transgender. Coolhart \& MacKnight $(2015 ; 59)$ supports this strategy by promoting the preservation of young people living "stubbornly," where "their transgender status is ignored by others".

\section{Schooling and its environment}

For transgender children, the school setting plays a key role in providing them with appropriate education. Transgender children can be trained in many aspects of education, including professional school counselling. In each secondary government school, at least one school counsellor should be available, but counselling in schools was unpopular (Small, Kok \& Lee, 2013). In Malaysia, it is widely known that most students are afraid to meet their school counsellors, especially transgender children. Elizabethe \& Melissa (2014:405) state that several participants stressed that the 'newness' of the 'issues' is a key factor. Furthermore, some of the school counsellors may not be qualified to care for transgender children at school as well as to train them for college.

The counsellor, however, has to attend counselling courses for transgender children at all levels of schools or participate in some professional counselling seminars and workshops. It is structured to ensure different approaches to every level of students. The transgender children needs special treatment but not their peers. These transgender children require special care and attention. They will be alienated, angered by the unfair care they get, leaving school and others. Therefore, the professional school counsellor must develop his or her expertise, knowledge and personal difficulties in working with transgender children. In addition, Islamic education should also be instilled among students.

\section{Islamic teaching}

Malaysia has integrated Islamic teachings from pre-school to university levels as a Muslim majority country. In order to address the transgendered problem of children at school, Islamic education based on the idea of morality and gender should be emphasized and enforced. A research carried out by Lihanna (2004) has shown that some children chose to play with the same gender during class. The question arises for transgender kids if they were eligible to play in boys or girls of a different gender. 
The instructor must consider these desires to understand the transgender children dilemma and solve the issue at an early stage.

As a central part of Islamic theology, the principles of faith and confidence in Allah must be central. Allah is the one who produced man and woman and there is a hermaphrodite (Khunsa) question in some cases. Accordingly, when children are born hermaphrodites, Ani Amelia and Zaleha (2016) explain that they only have a single organ from which the urination was performed. They are described as men, women and hermaphrodites in Islam. It is important to stress that no transgender identity is raised in Islam. However, transgender children at this point can only concentrate on the three sex groups. For hermaphrodite, the most important genital components confirmed by a medical practitioner must always be clarified. The transgender children may be included by their teachers, school counsellors and parents to be their preferred gender.

\section{The Transgender Children in Malaysian School and practicality of ISE}

Islamic sexual education (ISE) particularly taught to among Muslims is undergoing the preliminary stage in Malaysia. Muhamad Zahiri (2005) reports that Malaysia's Ministry of Education revamped both primary and secondary physical and health education in 1995. Several topics have been applied to the subject such as personal health, fertility and menstruation. In relation to modernisation, however, ISE would be updated and researched on the special modules for transgender children, concentrating on primary and secondary school transgender children. Nurtihah et al. (2014) applied al-adab to the framework model of cognitive theories. According to Nurtihah et al. (2014), 75\% of respondents have been hesitant to speak to their children about the sex education. In addition, $79.5 \%$ were undecided on sex education and content, and $75 \%$ had insufficient awareness of sexual education. However, the respondents discovered from book (88.6 percent), VCD (81.8 percent), and the internet (63.6 percent) about sex education. Islamic sexual education can be classified into three tiers as follows: elementary, primary, and secondary;

This could be widely understood that transgender children are special in Malaysia when it comes to their gender identity and voice. In all schools in Malaysia, irrespective of primary or secondary level and the private and public sector, the Islamic sex education module should be introduced. However, different viewpoints from the teacher, parents and children are important. According to research by Johari et al. (2012), 95\% of those surveyed said that no formal sex education was being taught at school. The practicality of ISE in Malaysia's transgender education can be applied in its entirety if the three elements are parental engagement, teacher preparation and the children's perspective can be integrated. Parental engagement can be developed by working together with schools and families. In addition, teacher's ability to attend special seminars and lessons to educate children should be encouraged. Finally, the children's viewpoints should also be considered in the Islamic Sexual Education,

A broad range of research has demonstrated that sex education should be taught on the basis of the various children's age (Abdullah Nasich Ulwan (2009), Mastura (2002), Yusof Madani (2003), Rokiah (2007) and Amir Hasans Dawi (2009). This is to better expose the children to Islamic teachings that are appropriate to their age. The three phases of children in adab (manner) and requesting permission can be identified at the age of 7-10 years. They should be advised to prevent from pursuing their lusts when they hit puberty at the age around 10-14 years. When they are 14-16 years old, they should teach the $a d a b$ of sex and take care of their honour. It ensures that the children are supervised and well informed with respect to many sexual orientations. In the training of transgender children, parents, teachers, school counsellors should refer to the Islamic Sex Education and focused on the teaching of Al-Quran and Hadith.

\section{RECOMMENDATION}

In the Malaysian community, transgender children need special attention in preparing them for better education. Although the implementation of ISE remains fresh, transgender children need to be directed and cared to stay in their identity. It can be shown that transgender children should obtain appropriate education in elementary, primary and secondary schools as well as in other schools. In a research 
conducted by Varjas et al. (2008), LGBT victims of bullying can be divided into three: verbal assault, oral violence, and physical attack. Work by Kivel \& Kleiber (2000) and Van Wormer (2003) are widely accepted as transgender children were often subjected to bullying due to homophobic behaviour among school children.

In addition, transgender children should be taught in an Islamic course consisting of Sharia, Akhlak, and Akidah, which are the core of Islamic principles. Once they have learned ISE, they might stop being transgender. In addition, multiple studies have shown that stigma, harassment of own parents, peers and teachers have removed transgender children from school. In conclusion, various participating parties have to help transgender children in completing their studies. The pre-school, secondary and primary schools in some Klang Valley area are to conduct a qualitative research employing a semi-structured interview and an open-ended questionnaire to examine how well transgender children are able to improve their sexuality in line of ISE modules.

\section{CONCLUSION}

In Malaysian schools, transgender children are new issues that need to be pursued to ensure their future. In this study, since this is a very sensitive subject and concerns, the researchers need to investigate and gain information on the number of transgender children in Malaysia. In addition, ISE, which included the implementation of transgenderism, would commence at elementary, primary and secondary schools in three phases. The overview to transgenderism can be a part of any relevant subjects such as Science, Biology, Islamic Education, Civics and Nationhood. As for the study, it was noticed that Malaysia is not yet in favour of promoting transgender children, notably in educational settings. During their school times, the majority of transgender people in Malaysia including children are found to suffer a greater challenge, persecution and bullied while they were attending schooling.

\section{REFERENCES}

Anneliese, A. S. \& Theodore, R. B. (2009). Creating Developmentally Appropriate, Safe Counseling Environments for Transgender Youth: The Critical Role of School Counselors, Journal of LGBT Issues in Counseling, Vol 3:3-4, 215-234.

Ani, A.Z and Zaleha, A.M. (2016). The Islamic Perspectives of Gender-Related Issues in theManagement of Patients With Disorders of Sex Development. Archives of Sexual Behavior. Vol 46 (2), 1-8.

Article 12. Gender Recognition Act: Accessed date 25 June 2019 http://www.oireachtas.ie/documents/bills28/acts/2015/a2515.pdf.

Azizah, J., Chan, S. L. (2008). Design Approach of Malaysian Sexual Educational Courseware (MSE) for Secondary Schools. e WSEAS Conferences in Istanbul, Turkey, May 27-30, 2008.

Brydum, S. (2013). 'Trans Six-Year-Old is Argentina's Youngest to Amend Gender on Birth Certificate' in The Advocate. 28 September 2013. Accessed date 25 June 2019 at: www.advocate.com/politics/transgender/2013/09/28/trans-six-year-old-argentinas-youngestamend-gender-birth.

Coolhart, D. \& MacKnight, V .(2015). Working with Transgender Youths and Their Families: Counselors and Therapists as Advocates for Trans-Affirmative School Environments, Journal of Counselor Leadership and Advocacy. Vol 2 (1), 51-64.

Department of Statistic Malaysia (2018). CHILDREN STATISTICS PUBLICATION, MALAYSIA. 2018.

Ehrensaft, D. (2009). One pill makes you boy, one pill makes you girl. International. Journal of Applied Psychoanalytic Studies, Vol 6(1), 12-24.

Elizabethe, P \& Melissa, S. (2014). The Big Freak Out: Educator Fear in Response to the Presence of Transgender Elementary School Students, Journal of Homosexuality, Vol 61:3, 399-418.

German Federal Court from March 16, 1982, Reference number 1 BvR 938/81

Greytak, E. A., Kosciw, J. G., \& Diaz, E. M. (2009). Harsh realities: The experiences of transgender youth in our nation's schools. New York, NY: GLSEN. 
Human Rights Watch. (2014). Europe: Progress for Transgender Rights. Accessed date 7 July 2019 at: http://www.hrw.org/news/2014/06/24/europe-progress-transgender-rights

Jahan, N., Naveed, S., Zeshan, M., \& Tahir, M. A. (2016). How to Conduct a Systematic Review: A Narrative Literature Review. Cureus, 8(11)

Jin, K. K. \& Sew, K. L. (2017). Proposing a collaborative approach for school counseling, International Journal of School \& Educational Psychology. Routledge; Taylor and Francis Group.

Johari, T., Maharam, M., Maznah, I. \& Zulkifli, M. (2012). Analysis on sex education in schools across Malaysia. Procedia - Social and Behavioral Sciences. Vol 59 ( 2012) 340-348.

Julia, T. N., Jake, P., Kelley, W., Stephen, F., Cindy, H., Jemma, T., Mari-Lynne, S., Ally, J. \& Sarah, P. (2018). A critical commentary on follow-up studies and "desistance" theories about transgender and gender-nonconforming children, International Journal of Transgenderism. International Journal of Transgenderism. Taylor \& Francis Group,1-13.

Kosciw, J. G., E. A. Greytak, N. M. Giga, C. Villenas, and D. J. Danischewski. (2016). The 2015 National School Climate Survey: The Experiences of Lesbian, Gay, Bisexual, Transgender, and Queer Youth in Our Nation's Schools. New York. NY: Gay, Lesbian and Straight Education Network (GLSEN).

Kosciw, J. G., Greytak, E. A., Diaz, E. M. \& Bartkiewicz, M. J. (2010). The 2009 National School Climate Survey (New York, NY, Gay, Lesbian, and Straight Education Network).

Kristopher, G \& Janalee, B (2018). Transgender and gender nonconforming students in schools: one school district's approach for creating safety and respect, Sex Education. Journal of Sexuality, Society and Learning, 1-14.

Lily, M.M and Azman, M.N.A. (2013). Preschool Education in Malaysia: Emerging Trends and Implications for the Future. American Journal of Economics. Vol 3(6), 347-351.

Low, S. K., Kok, J. K., \& Lee, M. N. (2013). A holistic approach to school-based counselling and guidance services in Malaysia. School Psychology International, 34(2), 190-201.

Luecke, J.C. (2011). Working with Transgender Children and Their Classmates in Pre-Adolescence: Just Be Supportive. Journal of LGBT Youth, Vol 8, 116-156.

Mark, H. (2009). Transgender Children in Schools. Liminalis: journal for sex/gender emancipation and resistance, 81-99.

McCarthy, L. (2003). Wearing My Identity: A Transgender Teacher in the Classroom, Equity \& Excellence in Education, Vol 36 (2), 170-183.

Mohammad Kowsar, B. (2014). Inclusion of Sex Education in School Curriculum of Bangladesh: Parents' Attitude. IOSR Journal of Research \& Method in Education. Vol 4 (5), 32-40.

Mokhtar, M., Mursyidah, I., Nor Atiah, Nangkula., Utaberta., Mohd Yunos, Mohd Yazid., Ismail, Sumarni., Ariffin and Noor Fazamimah (2015). Understanding Islamic education for pre-school children in Malaysia. Advances in Environment Biology, 9 (24). pp. 118-120.

Muhamad Zahiri, A.M. (2005). Values underpinning sex education from an Islamic perspective: Implication on the sex education in Malaysian curriculum. $\mathrm{PhD}$ theses. International Islamic University Malaysia.

National Human Rights Society Malaysia. (2018). Report on: Bullying in Malaysian Schools.

Neary, A., and Cross, C. (2018) Exploring Gender Identity and Gender Norms in Primary Schools: The Perspectives of Educators and Parents of Transgender and Gender Variant Children, Limerick: University of Limerick and the Transgender Equality Network of Ireland.

No Author. Article 5 of the Argentinean Gender Identity and Health Comprehensive Care for Transgender People Act (Decree No. 773/12, of Gender Identity

Act No. 26.743).

Nurtihah, M. N., Abdul Nasir, Z, Mohd Fitri, Yusoff., Fadzilah, S. (2014). Islamic Sex Education (ISE) Conceptual Model of Cognitive Theories-The Findings. Jurnal Teknologi. Vol 68 (2), 13-18.

Olson, K.R. \& Enright, E.A. (2017). Do transgender children (gender) stereotype less than their peers and siblings? Developmental Science. John Wileys \& Sons Ltd.

Olson, K.R. (2016). Prepubescent Transgender Children: What We Do and Do Not Know. Journal Of The American Academy Of Child \& Adolescent Psychiatry. VOL 55 (3), 155-159.

Olson, K.R., Key, A.C and Eaton, N.R. (2015). Gender Cognition in Transgender Children. Psychological Science. Vol 26(4), 467-474 
Rebecca, L. S., Jody, L.H., Amira, H. Transgender parenting: A review of existing research. The William Institute. University of California.

Roziana, Z., Aminudin, H., Juhazren, J and Siti Suhaila, I. (2018). Sexual Exposure Among Primary School Children. International Journal for Studies on Children, Women, Elderly And Disabled, Vol 4 (6), 46-52.

Vadevelu, K., Singh, P. S. J., Firdaus, R. B. R., Samsurijan, M. S., Latif, A. R. A., \& Haizzan, M. (2018). Transgender Coping Strategies Dealing with Family Members in Penang, Malaysia. International Journal of Academic Research in Business and Social Sciences, 8(2), 85-96.

Varjas, K. Dew, B., Marshall, M., Graybill, E. Singh, A., Meyers, J. \& Lamar Birckbichler, L. 2008. Bullying in Schools Towards Sexual Minority Youth, Journal of School Violence, 7:2, 59-86

Victor, L. (2008). Systematic Reviewing in the Social Sciences: Outcomes and Explanation. Journal of Enquire. Vol 1 (1), 32-46.

Wong, Y. (2004). Sex education, start from children born, Early Childhood Education, Vol 22, 9-10.

Yik, K.T. (1998). Understanding the Problems of Mak Nyahs (male transsexuals in Malaysia). South East Asia Research. Vol 6 (2), 165-180.

Yik, K. T. (2001). Mak Nyahs (male transsexuals) in Malaysia. The Influence of Culture and Religion on their Identity.

Zaini., Fadilah, Ab. Rahman, Hamidah , Md. Shah, Ishak, Abd. Kadir, Hamdan .(2004). Pengaruh pelajar lembut terhadap perkembangan sahsiah pelajar dan imej UTM menuju ke arah "World Class University". Project Report. Universiti Teknologi Malaysia. (Unpublished). 